\title{
Introducing the Feminist Management Discourse in Organizations
}

\author{
Aagoth Elise Storvik \\ Institute for Social Research \\ Munthes gate 31, Pb. 3233 Elisenberg, 0208 Oslo, Norway \\ Tel: 47-23-086-100Ｅ-mail: aas@samfunnsforskning.no
}

$\begin{array}{lc}\text { Received: December 6, } 2011 & \text { Accepted: January 13, } 2012 \quad \text { Published: March 1, } 2012 \\ \text { doi:10.5539/res.v4n1p155 } & \text { URL: http://dx.doi.org/10.5539/res.v4n1p155 }\end{array}$

The research is sponsored by the Norwegian Research Council and the Ministry of Government, Administration and Reform.

\begin{abstract}
The article demonstrates management discourse without masculine subtexts. In two organizations in the Norwegian state administration management was talked about either as a truly gender neutral activity or as a "feminine" activity. Managers' primary tasks were to motivate team members and help them develop their capacities, it was stated. Further, team management was described either by the use of metaphors from gardening or childcare. Management discourse without a masculine subtext still appears to be very uncommon in work organizations. Why the typical masculine gendering of management was swapped with a more neutral or even feminine gendering is discussed in the article. It is argued that the successful launching of a non-masculine discourse relied on feminist agents who very effectively created organizational structures supporting such a discourse.
\end{abstract}

Keywords: Management discourse, Feminism, State bureaucracy, Gender

\section{Introduction}

Gender stereotypes and gendered occupations and positions are often believed to be two of the most crucial mechanisms by which power differences between men and women are created in working life (Ragins and Sundstrom, 1989; Valian, 1999; Eagly and Carly, 2007). (Note 1) In this article I will focus on gendered subtexts in management discourse. Through the study of two organizations in the Norwegian state bureaucracy, I will demonstrate how management here is discussed without masculine subtexts. The background for this rather unusual finding will also be scrutinized. I will argue that feminists in central positions of power inside the bureaucracy have played a vital role in launching this non-masculine management discourse.

In her famous book Men and Women of the Corporation, Rosabeth Moss Kanter (1977) points out that under the cover of gender neutrality a masculine ethos exists in earlier management theories. Control, purposive rationality and authority are stated as characteristics of management forms such as taylorism and the weberian bureaucracy. (Note 2) However, in team management, a more contemporary form of management, the gendering is no longer masculine. According to Clegg (1995), a feminine ethos is here lurking just beneath the surface. This immanent femininity has not been acknowledged in management literature (Fondas, 1997; Hatcher, 2003). According to Metcalfe and Altman (2001), one problem not yet thoroughly studied is what happens when teamwork and team management are introduced in organizational life. Is the feminine subtext also suppressed in this context or do even masculine subtexts emerge? According to Broadbrige and Hearn (2008:44), there still is a masculine gendering of management in most organizations. Moreover, Schein (2007) concludes that the strength and flexibility of the "think manager- think male" attitudes held by men in her study are very persistent across time and national boarder.

Since Kanter (1989) pointed out the masculine ethos in management constructs, working life has gone through major transformations and bureaucratic modes of organization have lost their popularity. Smaller and more flexible teams of workers are now often in textbooks described as ideal (Piore and Sabel, 1984; Sennett, 1998). 
(Note 3) Team management is here outlined as different from earlier management styles (Kanter, 1989; Clegg, 1995; Fondas, 1997; Hatcher, 2003). Planning, organizing, staffing, directing, coordinating, reporting and budgeting are cited as outmoded management skills in textbooks. Such ways of organizing are associated with steep hierarchy and rigid departmentalization. In opposition to this the new way of managing, team management, is supposed to require that managers coordinate, facilitate, coach, support and nurture their employees (Procter and Mueller, 2000).

Smith and Smits (1994) argue that a feminization of management has occurred in the later two or three decades. Feminization is a term used to describe different process in working life, and it can at least refer to three different developments (Adkins, 2001:670). Firstly, feminization of management can mean that women increase their share of management positions. This increase is often accompanied by some sort of gender re-segregation process occurring inside the occupation (Tienari, 1999; Bolton and Muzio, 2008). Secondly, the term can also mean that management jobs are redesigned to terms, conditions and organizational structures associated with women's work. Thirdly, feminization can also mean a request for or the appearance of more "feminine" styles of management. (Note 4) This third type of feminization is the focus in this article.

Calás and Smircich (1993) and Alvesson and Billing (2009) argue that there is good reason to be skeptical about the extent of radical change regarding leadership and the need for female skills. They point out that there might only be superficial changes behind the new rhetoric, and Cunha and Cunha (2002) even argue that a masculine ethos, in the form of a search for profitability and status, can underlie feminine management practices. On the other hand Fletcher (2004:651) argues that a new type of leadership has emerged - "post heroic leadership" which demands traits more rooted in feminine-linked images and wisdom about how to "grow people" in the domestic sphere. The problem for women, Fletcher argues, is that this might look as they just behave in their traditional role while men are doing something new. Adkins (2001) parallels Fletcher and argues that even though management is supposed to require more feminine skills this does not necessarily benefit women. It is possible that men are seen as the best performers of femininity as women are only seen as naturally feminine. As women also are forbid to appear masculine, they become disadvantaged in the competition for management positions.

The article starts by outlining earlier research on gender and management and particularly gender and management discourse. This is followed by a recapturing of some theoretical insights crucial to discourse analysis. I then present case studies of two organizations. Through in-depth interviews with managers, discursive practices are explored. In the final section, I discuss the theoretical implications of the study.

\section{Theoretical Framework}

Management and gender is a research topic which has received a great deal of interest and many contributions in the last three decades. According to Alvesson and Billing (1999:43) and Halford and Leonard (2001:102), two questions have been particularly prominent in this research area: do men and women have different management styles and why are there so few female managers? These questions have been studied from many different angles and competing explanations have been offered. The discourse perspective, which this article departs from, has been used to study both these research questions (Ashcraft, 2004).

The discourse perspective on management can be divided into four different subgroups (Ashcraft, 2004). The first perspective studies gender differences in management style and asks if women and men in management have different communication styles. Tannen (1994) argues that women at the workplace talk to create a feeling of togetherness and therefore avoid self-promotion. According to Loden (1985) and Helgesen (1990) women's ways of communicating in leadership position might in some cases be superior to men's styles. The second perspective looks at how management is talked about and gendered in organizations. Here gender is the product of the discourse and not the cause. The work of West and Zimmerman (1987) on "doing gender" is an important fundament for this perspective. Several studies have looked upon how people discuss gender and management in organizations. Collinson and Hearn (1996) show how different organizational settings contribute to different types of masculine management. Kvande (2002) studies how implementation of new public management in public service organizations leads to a masculine re-definition of management. Metcalf and Linstead (2003) find that team management is reinvented and talked about in masculine terms in a blue-collar factory. They point out that discourse practice must be understood in relation to power relations in an organizational context. On the other hand Carvalho and Santiago (2009:618) find that female nurses acknowledge, emphasize and articulate feminine aspects of hospital management, in addition to masculine aspects. Similarly, Gremmen and Benschop (2009) find that account manager emphasize both masculine and feminine aspects of their role. 
The third perspective looks at how organizational structure is gendered. Organizations influence interaction by predisposing and rewarding employees to act in certain ways. However, organizations are also created and redesigned by employees' actions. The third perspective emphasizes the collective aspect of discourse at the "meso" level which crystallizes into organizational structures. Ferguson (1984) sees large bureaucratic organizations as constructs particularly problematic for women. (Note 5) Benschop and Dooreward (1998) argue that the organization of tasks and the division of jobs are undertaken according to gendered principles in banking. As an example, they show how part-time jobs, so called "mommy-tracks", do not involve work which can lead to promotion. Acker (1989) point out that an implicit assumption in the way management positions are designed, e.g. long working hours, travelling, being available, is that the manager has a partner at home who takes the main responsibility for the family. Social conventions make it easier to handle this task over to women than men.

The fourth perspective looks beyond the actual organization to the macro level. Here one studies how management and gender are discussed in society-at-large, such as in research and popular culture (literature, film, advertisement etc.). Several studies of management literature such as Kanter (1977), Fondas (1997), Cunha and Cunha (2002) and Hatcher (2003) fall into this category. Further, Calás and Smircich (1993) have studied how the discourses about globalization and "feminine" leadership get entangled. They find that managers who are at home become feminized and managers at the international ground are masculinized. The latter group is seen as superior.

Ashcraft (2004:289) argues that the four perspectives can and should be combined, and in this article I will attempt to do so. The second perspective is the main focus in this study, but the other three perspectives also come into the analysis in different ways. The interviewees are asked about perceived gender differences - the topic for studies in the first subgroup. Moreover, organizational structures and management literature, the topics of respectively the third and the fourth subgroups, are used to explain managers' discursive constructs at the micro level, i.e. the topic in subgroup two.

In this article, discourse is studied both as structure and action (Dijk, 1997:3). As structures, discourses are studied as institutionalized chains of arguments and typical uses of metaphors and characteristics. This means that I will look upon which characteristics are used to describe team management and which metaphors are used to illustrate it. In addition I will also look at how the relation between gender and management is outlined, which arguments are put forward to describe the relationship. As action, I focus on the intentional aspect of talk. What do different actors hope to achieve by their talk about management and gender, is the question I ask.

Discourses themselves are both influenced by power relations and in turn, influence power relations (Fairclough and Wodak, 1997:258). This view contradicts that of Michel Foucault who only sees discourse as constitutive of power relations, and not the other way around (Dijk, 1997). How management and gender is conceptualized has consequences for who is appointed to be managers, i.e. who has the claim to powerful positions. Moreover, power influences how management is constructed in discourses. According to Mumby (2004:240), critical discourse studies can mainly be characterized by two broad themes: ideological domination and reproduction, and struggle, resistance and transition. This article can mainly be placed in the last category.

Discourses cannot be understood without taking the social and historical context into consideration, and they also relate to other discourses in the past and in the present. Discourses work together with other social practices, Fairclough and Wodak (1997) argue. In this study I will show how organizational structures work to establish and sustain a certain discourse about gender and management.

Studies about gender constructs are always in danger of reifying what they want to deconstruct, namely gender (Alvesson and Billing, 1997; Gremmen and Benschop, 2009). However, not naming certain elements of management construct as feminine or masculine do not make the gendered subtexts go away. Instead it is left to operate at a more unconscious level where it can be just as persuasive and more difficult to confront.

\section{Methods}

Both organizations in this study were working with economic issues in the state bureaucracy. One of the organizations was very prestigious and employed only the most academically successful people. The other organization had not the same high esteem, but was considered an interesting step stone to more well paid jobs in private companies. Usually the employees in both organizations had higher degrees in economics or law (Note $6)$.

Each workplace was also male dominated, and especially at the higher levels. In both organizations there were ten top management positions, and only one of these was occupied by a woman. At the mid-level about 25 per cent of the managers were women. This meant that both organizations had fewer women managers than what 
was the average in the state bureaucracy at the time. Not surprisingly, she was head of the administrative department, a management position which is often handled over to women (Alvesson and Billing, 1997). At the mid level, women managers were found in almost all departments, also in the most prestigious. Both organizations had an internal labor market. New managers were often recruited from inside the organizations. Academic qualifications were previously the main criteria in management selection. In the last two decades this had lost some of its importance (Statskonsult, 2000:32).

The selection of public organizations was done according to the principle of strategically selecting cases where a certain phenomenon, i.e. masculine gendering of team management, was most likely to be found. (Note 7) Because of this, I chose to study organizations working in "masculine" fields with many men employed. (Note 8)In both organizations all managers worked full time. Part-time work was common at lower, non-professional levels such as among secretaries and other staff in service functions.

The method used was in-depth interviews with managers at the mid and top level. I conducted the interviews in the year 2002. The aim of the study was presented as to investigate management practices and experiences, ambitions, working conditions and gender. That the study was initiated and financed by the Ministry of Government, Administration and Reform must have supported the impression that this was the true mission. It was made clear that all participation in the study was voluntary and that interviews would be confidential. Nearly all managers who were asked to participate agreed to this at once. They all seemed to find the questions appropriate and some managers said that they found the topics interesting. Tienari (1999) found that gender and management was not an appreciated topic when they interviewed managers in a Scandinavian bank. That managers in this study reacted differently must be understood on basis of the organizational context where gender and management was a question which was continually on the agenda, because of the political wish to create more gender equality in the state bureaucracy. Most of the managers also seemed to enjoy the interview situation and no one seemed particularly restrained. My own age and educational background were very similar to the interviewed managers and this might have created the relaxed atmosphere.

The interviews were formed to tap both conscious and more unconscious constructions of gender and management (Kvale, 1997). The interviews started with a question about management ideals and practices. Gender differences in management were introduced as a topic first at the end of interviews. This was done in order to secure that their opinions would not influence their general descriptions of their own management ideals and practices (Martin, 2001:595). Managers were in addition asked about working conditions, organization culture, family responsibilities and working hours.

In one organization, eight female managers and six male managers were interviewed, and in the other organization, six male and ten female managers were interviewed. Two top managers were also interviewed in both organizations. The mid-level managers were from different departments in the organizations and from lower and higher levels of the mid segment. Managers were selected so that most departments should be represented in the study. In a department where one male manager was interviewed also a female manager was interviewed, but not always the other way around because more women were interviewed. Managers from two-thirds of all departments in both organizations were included in the study.

All interviews lasted from one to two hours and were recorded and later written down. The written material was scrutinized to identify statements about management and gender, both of an explicit and a more implicit character. Firstly, each interview was looked upon separately to identify unity and inconsistence regarding gender and management constructs. Secondly, all interviews were analyzed together to identify similarities and difference in the constructs. If differences were identified, I looked upon what they were and if they differed between groups (gender, management level, organization).

To understand more about the context the discourse occurred in, three steps were taken. Firstly, documents about the introduction of team work and the work with gender equality in the state were gathered. A complete selection of documents contained reports to the Storting, reports from a directorate involved in the processes (Statskonsult) and a research report from a private independent institute (SINTEF).

Secondly, one advisor and a consultant who had worked with the issues of gender equality in the state were interviewed. The two persons worked in two different state entities (a directorate and a ministry) and both of them played important roles in the government's efforts to increase the number of women managers. The interviews were about the work they had done, their experiences and personal views. This material will be used as background information to account for the findings in the case studies.

Thirdly, two top managers in a large private company were also interviewed about management and gender issues in their organization. These interviews were conducted to see if the management discourse here had 
another content and framing. This material is only used as a background for the other two case studies presented here and will therefore not be presented as a third case.

What people say in interviews might not be representative for what they say in other settings. Silverman (1986) argues that what people say in interviews is often best seen as ideological representations of themselves. This is of course often true, but in this case it is not a problem. The aim here is to study how people in fact discuss leadership in formal settings in the organizations and not what their "true feelings" about the topic might be. The promised confidentiality in this study might potentially stimulate more explorative and non-conforming talk than in other more formal social settings at the workplaces. Nevertheless, other more informal discourses on the topic might exist in the organizations, such as when employees socialize in smaller groups in private settings.

\section{The State Bureaucracy Context}

The number of female managers in the public sector has steadily increased to 55 per cent in 2008, while in the private sector only 24 per cent of all managers were women (Statistics Norway). (Note 9) In the private sector little effort has been made to increase the number on female managers, contrary to the state sector. (Note 10) Here many steps were taken to reach the goal.

In the state administration the launching of teamwork and the effort to increase the number of female managers became inter-winded organizational processes occurring in the same time span. A quick glance backwards demonstrates this. During the last two decades, since the beginning of the1990s, the Norwegian state administration has undergone significant changes (Statskonsult, 2000). The old civil servant tradition lost some of its terrain due to new work tasks (Byrkjeflot, 1997). The new work tasks were considered to be best served through teamwork, which again demanded a new management style, namely team management (St.meld. nr. 35, 1991-92:60). It was decided that one directorate, at the time called Statskonsult, should be responsible for the reorganization and should promote team work through the arrangement of management courses (Statskonsult, 2000:38).

At the same time as these changes were going on, work was also done to secure gender equality in the state administration. (Note 11) The Norwegian Parliament decided that the percentage of female managers in the state administration had to be raised and work to accomplish this started in the late 1980s (SINTEF, 1996:2). Because of the political demand, the state administration developed plans and programs to achieve this goal. The interviews with the former mentioned advisor and consultant revealed that these tasks were mainly handed over to female bureaucrats who were feminists.

Many new organizational procedures and routines were launched. One reform introduced gender equality as a topic in the former mentioned training programs for managers (St.meld.nr.35, 1991-92). In the report no. 35 to the Storting it was now stated that the courses also should be used to develop the right attitudes towards gender equality generally and female managers specially (St.meld.nr.35, 1991-92:51). Further these issues were also launched in seminars, workshops and conferences. Consultants and researchers were often invited to speak here. Their competence on the issue was often acquired through reading American gender and management literature (Larsen, 1999). (Note 12) The result was that managers and also employees at lower levels were introduced to the feministic discourses on gender and management through the courses and workshops.

The other important organizational change was that gender equality was made a manager responsibility. Directions from the political level demanded that all managers in the state administration should work to accomplish gender equality in the field under his or her authority (St.meld.nr.35, 1991-92:61; Statskonsult, 2001:27). It was also stated that this implied working for recruiting more women managers where there was a lack, i.e. less than $40 \%$. Further manager were informed that they would be measured on their performance on these matters.

\section{Management Discourse and Gendered Subtexts}

All mid-level managers who were interviewed expressed similar ideas about management. They argued that "Managers should be supportive and show concern for their subordinates"; "A good manager should help co-workers to develop their potential and motivate them to do their best". Further, they said that "Managers should have good communication skills and be able to create a feeling of togetherness". This was important for managers at all levels, according to mid-level managers. Top managers mentioned these kinds of skills too, but added that it was important that a top manager also was able to take initiative and to act.

Obviously, the ideal they all expressed was team management. The ideal was reflected in opinions about what characterized good leadership, in descriptions on how they themselves carried out their management tasks and in descriptions of successful managers they knew. If this was the way work really was carried out is another 
question which will not be studied here. As mentioned much of the old hierarchical organizational structure was still retained and this could probably create barriers for team work. However, all managers asserted that they worked according to team work principles.

The next question I shall turn to is the gendered subtexts in management talk. First, I shall look at the use of metaphors and words used to describe team management. This dimension of language might in some cases reflect somewhat more unconscious understandings (Fiske, 1982; Alvesson, 1993). Talk about team management during the interviews was characterized by metaphors from childcare and gardening. One woman talked about management this way:

"It is important for a manager to show concern for her team members. As with plants, you have to water and nurture them in order to make them grow and develop their potential"

Not all managers compared coworkers to plants, as the one cited above, but they all described management as either a truly gender neutral or "feminine" task. To help co-workers "to grow" and to help them "develop their abilities and potential" were common expressions. These kinds of metaphors were used both by men and women, but they were more prominent among women. Further, some women mangers also used metaphors with associations to motherly concern to describe their relations to team workers. They talked about "nurturing" and "comforting" subordinates. None of their male colleagues used these expressions. What one can conclude from the use of characteristics and metaphors is that there was not any implicit masculine gendering of management. Rather, the metaphors seemed to have a vague or more pronounced femininity attached to them. (Note 13) It was also evident that male managers used a more gender-neutral language than female managers.

This tendency was emphasized if we look at the managers' more explicit opinions. When they were asked to reflect on differences between male and female managers in their organization, a distinct picture emerged. According to the men there were no differences in management practice. One male manager put it this way: "Everybody is different. Some are good at this and some at that. This is not related to being a man or a woman." The women managers did not agree. In their opinion there was a salient distinction between men and women. The women also described this distinction equally. "Female managers show more concern for their team members", they claimed. They also argued that they were more eager to help their team members to develop their skills and to motivate them.

Female managers described many different kinds of concern and help which they thought were typical only for female managers. One important aspect was paying attention to their team members' private lives. This orientation took different paths. One manager said that she always congratulated co-workers when they got married or had a baby, and arranged a small celebration at work. Some of the other women managers said that they used to listen to the subordinates stories about their personal problems at home and tried to comfort them. Another manager mentioned that she tried to create a friendly atmosphere at work, through serving coffee and cakes now and then. Further, another manager said that she tried to motivate her team members by always asking their opinions and discussing decisions with them. Still another manager said that she tried to help out when the workload became too heavy for her team members. This meant that she had to carry out the tasks herself, and that she had to work longer hours. Except for these manifestations of social concern, there were no other significant gender differences in management, according to these women.

\section{Discussion and Conclusion}

As we have seen, team management is described either as gender-neutral or as a "feminine" skill. The managers own discursive constructs of good management do not have masculine subtexts. When management is described as gender neutral it is not just a cover, but also true at the deeper level of subtexts. Further, when management is described in feminine terms, the feminine ethos is acknowledged and articulated by women themselves. These gender-and-management constructs resemble what Alvesson and Billing (1997:143-147) describe as the feminist discourses, often found in American management literature. As we have seen, male managers favor the gender-as-sameness argument, while female managers favor the gender-as-difference and femaleness-as-an-advantage argument. The findings demonstrate Meyers (2005) point, namely that management discourses seem to move quite freely both between countries and between different sectors of society.

The non-masculine construction of management found in this study is very different from what most other studies report, as described in the introduction. Especially one could have expected that male managers would try to keep the masculine subtexts intact, as the coupling of masculinity and management is likely to have given men an advantage in the competition for management positions. 
So what can explain the rather unusual finding - management discourse without masculine subtexts? One possible explanation is the national context. Martin (2011:215) argues that studies of organizations should be viewed in a national perspective. Gibson and Zellmer-Bruhn (2001) show that cultural themes influence how teamwork is conceptualized. They found that different metaphors were used in different countries and that the choice of metaphors could be linked to national values. In addition they found that the most feminine metaphors were used in Scandinavia, while more masculine metaphors were common other places in Europe. Studies of national values also show that people in Norway and Scandinavia are more positive to gender equality than people in mid Europe (Bergh, 2007).

National context might have influenced the process to some extent, but interviews with two top managers in a very large Norwegian enterprise in the private sector point in another direction. The private managers' views on leadership were not very different from the views of managers in the state. The private managers also proclaimed that they were in favor of increasing the number of women managers in their organization, but no plans were made for how one should accomplish this. The way the private managers talked about management was, nevertheless, clearly different from the discourse in the state organizations. The metaphors they used were football playing and football coaching. They had picked up their ideas about good management from reading a book about the subject, written by a famous Norwegian football coach. Of course as management here was described as football coaching, the masculine subtexts were very evident. This observation indicates that national context might not be the crucial factor explaining the gendered subtext of management discourses in this case. Instead this finding points to the importance of organizational context.

In the Norwegian state bureaucracy, new organizational routines were launched and management instructions were changed, as already described. Gender equality was introduced as a topic in the new training programs for managers. Further, gender equality was also made a manager responsibility. This last reform meant that to be successful, managers at least had to appear as they worked to accomplish this goal. To take part in the feminist discourses on gender and management became in itself a symbol that one was doing ones job and that one had the right kind of attitude. (Note 14) The study shows that these means were indeed effective in establishing a gender neutral management discourse.

The state bureaucracy is not always this effective in handling its internal affairs. (Note 15) In this case the tasks were delegated to advisors and consultants, most often women. In interviews with two of the women responsible for the process it became evident that they felt very enthusiastic about the tasks and that they themselves were feminists. The advisor and consultant also claimed that this applied to other bureaucrats working in positions central to the process. These agents can be termed state feminists. According to Siim (1991:189) the term state feminism refers to feminists employed as administrators, bureaucrats and politicians in positions of power who work to promote gender equality policies. The term state feminism has developed somewhat since it was introduced by Helga Hernes in 1987, according to Stetson and Mazur (1995). Siim's (1991:189) notion of the term might be more in line with what Sawer (1990) calls femocrats, than with the institutional arrangements Hernes originally had in mind. However, if we adopt Siim's notion the study shows how state feminists successfully work to create gender equality inside the state bureaucracy.

While both men and women stick to the feminist discourses of gender and management, they choose different versions as we have seen. Men argue that there are no gender differences in management styles, while women argue that they show more concern for their team workers. This difference of opinion is striking as they talk about the conditions in the same organizations. Which tales are most accurate is difficult to say, and as Wajcman (1998) points out what managers say they do and what they actually do can be very different things. (Note 16) What this disagreement represents is perhaps what Gherardi and Poggio (2007:173) call "the micro-politics of power between men and women" or what Carvalho and Santiago (2009) call "gender as strategic action". By arguing that there are no gender differences in management, male managers avoid that their gender disqualifies them for management positions. By arguing the opposite female managers try to make their gender an advantage.

As stated the two organizations in this study were selected because they were working in typical masculine domains and had fewer women as managers than what is typical for organizations in the state sector. The reason behind this strategic sampling was that if a non-masculine management discourse was found here, it was also likely to be found in less male dominated organizations. A survey sent to bureaucrats responsible for the hiring of top managers in the state found a somewhat different management ideal (Storvik, 2002). At this top level a rather well-balanced combination of qualities both referring to masculinity and femininity was required. Together these findings demonstrate that a one-sided masculine management ideal is not likely to be found in any part or at any level of the state bureaucracy. 
Both Fletcher (2003) and Adkins (2001) point out that a feminized management ideal not necessarily benefits women, as earlier described. Nevertheless, earlier research on the Norwegian state bureaucracy has showed that women and men aspiring for management positions in fact often receive a fairly similar treatment (Storvik and Schøne, 2008). It is difficult to say if a non-masculine management discourse has caused the equal treatment or if these processes occur separately. Moreover, the number of female managers has increased considerably in both organizations since the study was carried out. In the two organizations respectively 50 and 34 per cent of middle managers now are women. (Note 17)

Organizational discourse can be produced without any relation to external reality (Bendl, 2008). A non-masculine management discourse might therefore be described as only a change in rhetoric if not other organizational changes also occur (Alvesson and Billing, 2009). As described, organizational structure can be seen as inherently gendered. The bureaucratic core values which Weber (1968) outlined have not changed, and Ferguson (1984) argues that they are inherently masculine. On the other hand, organizational structures have partly changed. Due to new work tasks, team work was introduced in the two organizations in the study. However, the steep hierarchical structure was kept and Ferguson describes the hierarchy as a masculine organizational principle. Further managers work conditions are also often gendered as Acker (1989) points out. In the two organizations in the study, more flexible work conditions had been introduced and a reduction in actual amount of hours managers worked had also occurred. It is therefore fair to say that organizational structures had changed to a somewhat lesser masculine design. If these changes were enough to anchor the non-masculine management discourse in practice is uncertain. Still, if discourse is constitutive also merely rhetoric constructs might be significant.

\section{References}

Acker, J. (1989). The Problem with Patriarchy. Sociology, 23, 235-240. http://dx.doi.org/10.1177/00380385890 23002005

Adkins, L. (2001). Cultural Feminization: "Money, Sex and Power" for Women. Signs, 26(3), 669-695. http://dx.doi.org/10.1086/495625

Alvesson, M. \& Billing, Y. D. (1997/2009). Understanding Gender and Organizations. London: Sage.

Alvesson, M. (1993). The Play of Metaphors (pp.114-131). In J. Hassard and M. Parker, Postmodernism and organizations. London: SAGE Publications.

Alvesson, M. (1997). Kroppsräkning, konstruktioner av kön i spåren av offentliga organisationer (pp. 312-340). In E. Sundin (Ed.), Om makt och kön i sparen av offentliga organisationers omvandling. Strockholm: SOU.

Ashcraft, K. L. (2004). Gender, Discourse and Organization: Framing a Shifting Relationship. In D. Grant, C. Hardy, C. Oswick and L. Putnam. The Sage Handbook of Organizational Discourse (pp. 275-298). London: SAGE Publications.

Bahus, M. (2001). Kvinner i advokatyrket - proletærer i advokatfullmektig ham? Lov og rett, 7, 413-427.

Bell, D. (1973). The Coming of Post-industrial Society. New York: Basic Books.

Bendl, R. (2008). Gender Subtexts -Reproduction of Exclusion in Organizational Discourse. British Journal of Management, 19, 50-64. http://dx.doi.org/10.1111/j.1467-8551.2008.00571.x

Benschop, Y. \& Doorewaard, D. (1998). Covered by Equality: The Gender Subtext of Organizations. Organization Studies, 19(5), 787-805. http://dx.doi.org/10.1177/017084069801900504

Bergh, J. (2007). Gender Attitudes and Modernization Processes. International Journal of Public Opinion Research, 19, 235-261.

Birkelund, G. \& Sandnes, T. (2003). Paradoxes of welfare states and equal opportunities: gender and managerial power in Norway and the USA. Comparative Social Research, 21, 201-41. http://dx.doi.org/10.1016/S0195-631 0(03)21007-3

Bolton, S. \& Muzio, D. (2008). The paradoxical process of feminization in the professions: the case of established, aspiring and semi-professions. Work, Employment\& Society, 22(2), 281-299. http://dx.doi.org/10.1 177/0950017008089105

Bragd, A., D. Christensen, B. C. \& Tullberg, M. (2008). Discourse as the means of community creation. Scandinavian Journal of Management, 24(3), 199-208. http://dx.doi.org/10.1016/j.scaman.2008.02.006 
Broadbridge, A. \& Hearn, J. (2008). Gender and Management: New Directions in Research and Continuing Patterns in Practice. British Journal of Management, 19, 38-49. http://dx.doi.org/10.1111/j.1467-8551.2008.

00570.x

Burchell, B. (1996). Gender Segregation, Size, Workplace and the Public Sector. Gender, Work and Organization, 3(4), 227-235. http://dx.doi.org/10.1111/j.1468-0432.1996.tb00062.x

Byrkjeflot, H. (1997). Fra ledelse til management? In H. Byrkjeflot, Fra styring til ledelse. Bergen: Fagbokforlaget.

Calás, M. B. \& Smircich, L. (1993). Dangerous liaisons: The "feminine-in-management" meets "globalization". Business Horizons, 36, 71-81.

Carvalho, T. \& Santiago, R. (2009). Gender as a "strategic action. New Public Management and the professionalization of nursing in Portugal. Equal Opportunities International, 28(7), 609-622. http://dx.doi.org/ $10.1108 / 02610150910996434$

Clegg, R. \& Palmer, G. (1995). The politics of management knowledge. London: Sage Publications.

Collinson, D. L. \& Hearn, J. (1996). Men as Managers, Mangers as Men. London: SAGE Publications.

Cunha, J. V. \& Cunha, M. P. (2002). Reading between the lines: unveiling masculinity in feminine management practices. Women in Management Review, 17(1), 5-11. http://dx.doi.org/10.1108/09649420210416796

Dijk, T. A. V. (1997). Discourse as Social Interaction. Discourse Studies: A Multidisciplinary (Introduction, 2). London: SAGE Publications.

Eagly, A. H. \& Carli, L. L. (2007). Through the Labyrinth. The truth about how women become leaders. Boston: Harvard Business School Press.

Fairclough, N. \& Wodak, R. (1997). Critical Discourse Analysis. In T. A. Dijk, Discourse as social interaction. Discourse Studies: A Multidisciplinary (Introduction, 2, pp. 258-284). London: SAGE Publications.

Ferguson, K. E. (1984). The Feminist Case against Bureaucracy. Philadelphia, PA: Temple University Press.

Fiske, J. (1982). Introduction to communication studies. London: Methuen \& Co. Ltd. http://dx.doi.org/10.4324/ 9780203323212

Fletcher, J. K. (2004). The paradox of post heroic leadership: An essay on gender, power, and transformational change. The Leadership Quarterly, 15, 647-661. http://dx.doi.org/10.1016/j.leaqua.2004.07.004

Fondas, N. (1997). Feminization Unveiled: Management Qualities in Contemporary Writings. Academy of Management Review, 22(1), 257-287. http://dx.doi.org/10.5465/AMR.1997.9707180266

Gherardi, S. \& Poggio, B. (2007). Gender Telling in Organizations: Narratives from male-dominated environments. Malmø: Liber AB.

Gherardi, S. (1994). The Gender We Think, the Gender We Do in Our Everyday Organizational Lives. Human Relations, 47(6), 591-610. http://dx.doi.org/10.1177/001872679404700602

Gibson, C. \& Zellmer-Bruhn, M. (2001). Metaphors and Meaning: An Intercultural Analysis of the Concept of Teamwork. Administrative Science Quarterly, 46(2), 274-303. http://dx.doi.org/10.2307/2667088

Gremmen, I. \& Benschop, Y. (2009). Walking the tightrope: Constructing gender and professional identities in account management. Journal of Management \& Organization, 15, 596-610. http://dx.doi.org/10.5172/jmo.15.5. 596

Hakim, C. (2002). Lifestyle preferences as determinants of women's differentiated labor market careers. Work and Occupations, 29(4), 428-459. http://dx.doi.org/10.1177/0730888402029004003

Halford, S. \& Leonard, P. (2001). Gender, Power and Organizations. Basingstoke: Palgrave.

Hatcher, C. (2003). Refashioning a Passionate Manager: Gender at work. Gender, Work and Organization, 10(4), 391-412. http://dx.doi.org/10.1111/1468-0432.00203

Helgesen, S. (1990). The female advantage: Women's ways of leadership. New York: Doubleday

Hernes, H. (1987). Welfare state and women power: Essays in state feminism. Oslo: Norwegian University Press. [Online] Available: http://www.gender.no/Topics/14 1298

Kanter, R. M. (1977). Men and Women of the Corporation. New York: Basic Books.

Kanter, R. M. (1989). The New Managerial Work. Harvard Business Review, 67 (6), 85-92. 
Kvale, S. (1997). Det kvalitative forskningsintervju. Oslo: Ad Notam Gyldendal.

Kvale, S. (1997). Det kvalitative forskningsintervju. Oslo: Ad Notam Gyldendal.

Kvande, E. (2002). Kvinnelige mellomledere i gradige organisasjoner, In A. Ellingsæter and J. Solheim (Eds.), Den usynlige hand? Kjønnsmakt og moderne arbeidsliv. Oslo: Gyldendahl Akademiske, 315-331.

Larsen, E. (1999). Fra likestilling til mangfold. Nytt Norsk Tidsskrift, 2, 114-125.

Loden, M. (1985). Feminine leadership, or how to succeed in business without being one of the boys. New York: Times Books.

Martin, J. (2011). Does Gender Inequality Ever Disappear? (pp. 213-230), In E. L. Jeanes, D. Knights and P. Y. Martin, Handbook of Gender, Work and Organization. Chichester: John Wiley \& Sons Ltd.

Martin, P. Y. (2001). 'Mobilizing Masculinities': Women's Experiences of Men at Work. Organization, 8(4), 587-618. http://dx.doi.org/10.1177/135050840184003

Metcalfe, B. \& Altman, Y. (2001). Leadership. In E. Wilson, Organizational behaviour reassessed: The impact of gender. London: Sage publications.

Metcalfe, B. \& Linstead, A. (2003). Gendering Teamwork: Re-Writing the Feminine. Gender, Work \& Organization, 10(2), 94-119. http://dx.doi.org/10.1111/1468-0432.00005

Meyer, J. (2005). Management Models as Popular Discourse, In J. Alvarez, C. Mazza, and J. Pederson (Eds.). The role of the Mass Media in the Consumption of Management. Scandinavian Journal of Management, 21 (2), 133-6.

Mumby, D. K. (2004). Discourse, Power and Ideology: Unpacking the Critical Approach . In D. Grant, C. Hardy, C. Oswick and L. Putnam, The Sage Handbook of Organizational Discourse. London: SAGE Publications, 237-258.

Petersen, T. (2002). Likestilling i arbeidslivet. Tidsskrift for samfunnsforskning, 4, 3-38.

Piore, M. \& Sabel, C. (1984). The Second Industrial Divide. New York: Basic Books.

Powell, G. \& Butterfield, D. (1997). Effects of Race and Gender on Promotions to Top Management in a Federal Department. Academy of Management Journal, 40(1), 112-128. http://dx.doi.org/10.2307/257022

Procter, S. \& Mueller, F. (2000). Team working: Issues, Concepts and Problems. London: Macmillian.

Ragins, B. R. \& Sundstrom, E. (1989). Gender and Power in Organizations: A Longitudinal Perspective. Psychological Bulletin, 105(1), 51-88. http://dx.doi.org/10.1037/0033-2909.105.1.51

Reskin, B. \& Padavic, I. (1994). Women and Men at Work. Thousand Oaks. California: Pine Forge Press.

Sawer, M. (1990). Sisters in suits: Women and public policy in Australia. Sydney: Allen and Unwin.

Schein, V. E. (2007). Women in management: reflections and projections. Women in Management Review, 22(1), 6-18. http://dx.doi.org/10.1108/09649420710726193

Sennett, R. (1998). The Corrosion of Character: The Personal Consequences of Work in the New Capitalism. New York: W.W. Norton\& Company.

Siim, B. (1991). Welfare state, gender politics, and equality policies: Women's citizenship in the Scandinavian welfare states. In E. Mehavn and S. Sevenhuijsen (Eds.), Equality, Politics and Gender. London: Sage, 175-193.

Silverman, D. (1985). Qualitative Methodology and Sociology. Aldershot: Gower Publishing Company.

SINTEF. (1996). Evaluering av regjeringens handlingsprogram for likestilling i departementene 1991-1994. Rapport fra forprosjektet, STF38.

Smith, P. L. \& Smits, S. J. (1994). The Feminization of Leadership? Training \& Development, 43-46.

Statskonsult. (2000). Lederskapsutvikling i departementene, Notat 2000-9. Oslo: Statskonsult.

Statskonsult. (2001). Lederskap og utvikling: Erfaringer med lederskapsutvikling i staten. Temahefte. Oslo: Statskonsult.

Stetson, D. M. \& Mazur, A. (1995). Comparative State Feminism. Thousand Oaks: Sage Publications.

Stortingsmelding nr.35 (1991-1992). Om statens forvaltnings- og personalpolitikk. Fundament for fellesskap. Oslo: Arbeids- og administrasjonsdepartementet. 
Storvik, A. \& Schøne, P. (2008). In search of the glass ceiling: gender and recruitment to management in Norway's state bureaucracy. The British Journal of Sociology, 59(4), 729-755. http://dx.doi.org/10.1111/j.1468 $-4446.2008 .00217 . x$

Storvik, A. (2002). Topplederrekruttering i staten. Betydningen av kvalifikasjoner nettverk og kjønn. Oslo: Institutt for samfunnsforskning, rapport 2002: 5 .

Tannen, D. (1994). Talking from 9 to 5: How women's and men's conversational styles affects who gets heard, who gets credit, and what gets done at work. New York: William Morrow.

Tienari, J. (1999). The First Wave Washed up on Shore: Reform, Feminization and Gender Resegregation. Gender, Work and Organization, 6(1), 1-19. http://dx.doi.org/10.1111/1468-0432.00065

Tienari, J. (1999). The First Wave Washed up on Shore: Reform. Feminization and Gender.

Valian, V. (1999). Why so slow? The advancement of women. Cambridge: The MIT Press.

Wajcman, J. (1998). Managing like a Man. Cambridge: Polity Press.

Weber, M. (1968). Makt og Byrakrati. Oslo: Gyldendahl Norsk Forlag.

West, C. \& Zimmerman, D. H. (1987). Doing gender. Gender and Society, 1, 125-51. http://dx.doi.org/10.1177/ 0891243287001002002

\section{Notes}

Note 1. Other explanations are lack of access to important networks, sexual harassment, lack of child-minding facilities and welfare state arrangements (Gherardi, 1994; Acker, 1989; Birkelund and Sandnes, 2001). Still, there are also other possible explanations connected to womens' choices of education and occupation and their work orientation (Petersen, 2002; Hakim, 1999).

Note 2. Taylorism is a management theory developed by Frederick Taylor, who was an engineer. Management is here based on logic and rationality, and Taylor called his theory for "scientific management" (Kanter, 1977). Max Weber (1968) characterized bureaucracy as the most effective form of organization. He describes bureaucracy as based on rationality alone, without any influence from feelings or personal considerations.

Note 3. These transformations have been labeled "the coming of post-industrial society" (Bell, 1973) and "the second industrial divide" (Piore and Sabel, 1984).

Note 4. The notions feminine and masculine here applies to traits or skills which stereotypically are attributed to either men or women (see also Fondas, 1997:258).

Note 5. This claim has not been supported by later research (see Reskin and Padavic, 1994; Powell and Butterfield, 1994; Storvik and Scøne, 2008).

Note 6. Burchell (1996) points out that gender segregation in working life also exists inside professions. This is very clearly the case with the law profession in Norway. The percentage of female lawyers is very low compared with the percentage of female law students. In Norway, the best male students become lawyers, while the best female students work in the state administration (Bahus, 2001). For the candidates with a degree in social economics, there are virtually no jobs in the private sector. The result is of course that a great majority work in the public sector.

Note 7. Silverman (1985) proposes this method, which he calls strategic sampling. If a phenomenon is not found where it is most likely to be found, one can assume that it will neither exists in other places.

Note 8. According to Alvesson (1997) the public sector is often viewed as "sheltered" and "feminine", in contrast to the private sector which is viewed as "unprotected" and "masculine". This means that the two organizations studied were "masculine" organizations in a "feminine" sector.

Note 9. http://www.gender.no/Topics/14 1298.

Note 10. In the private sector the only collective attempt was done by the main employers' union, The Confederation of Norwegian Enterprise (NHO), who offered and still offers management courses to talented female candidates.

Note 11. Exactly what the term gender equality in the state administration meant was unclear. It also appeared to be the case that different governmental organizations had different conceptions of what this meant for them. In many cases though, gender equality was seen as synonymous with the percentage of female managers in the organizations (SINTEF, 1996:42). According to Alvesson and Billing (1997:134) this is a common understanding in working life. 
Note 12. Popular contributions were here such books as Rosabeth Moss Kanter's book Men and Women of the Corporation and Marilyn Loden's article "The Female Advantage" (Larsen, 1999). While the first book was most popular among researchers, the second article was mainly most popular among consultants.

Note 13 . Which connotations these two activities give can of course vary in different countries. While childcare in most societies is seen as a female activity, this is not always the case with gardening. In Norway gardening, at least on an unprofessional level, is clearly seen as a very "feminine" activity.

Note 14. Bragd et. al. (2008) describe how discourse can serve a symbolic function in organisations.

Note 15. The state bureaucracy's programs to include more disabled persons and people from ethnic minorities in its work force have so far failed.

Note 16. Alvesson and Billing (1997) have reviewed the literature on gender differences in management. They conclude that most studies show either none or minor differences in management practices.

Note 17. Number of female managers at the top level had also increased in both organizations. The organization earlier without any women at top, now had 38 per cent female managers at this level. The organization with less than 10 per cent women now has 28 per cent female managers at the top level. 